\title{
Numerical evaluation of systematic errors of a non-invasive intracranial pressure measurement
}

\author{
Edgaras Misiulis $^{1,2}$,
}

\author{
Gediminas Skarbalius ${ }^{1}$,
}

\author{
Algis Džiugys ${ }^{1,2}$ \\ ${ }^{1}$ Laboratory of Combustion Processes, \\ Lithuanian Energy Institute, \\ Breslaujos St. 3, \\ 44403 Kaunas, Lithuania \\ Email: edgaras.misiulis@lei.lt \\ gediminas.skarbalius@lei.lt \\ algis.dziugys@lei.lt \\ ${ }^{2}$ Kaunas University of Technology, \\ K. Donelaičio St. 73, \\ 44249 Kaunas, Lithuania
}

Intracranial pressure $(I C P)$ monitoring procedure can be applied to aid in secondary brain damage prevention. A high invasiveness of commonly used ICP measuring methods poses a risk of complications, and therefore new non-invasive methods are currently being developed. A promising non-invasive ICP measurement method is based on the existence of pressure balance state, which is driven by the unique morphological property of ophthalmic artery (OA). The value of ICP can be obtained by evaluating blood flow or artery characteristics in different OA segments, intracranial OA segment (IOA) and extracranial OA segment (EOA).

In order to increase measurement accuracy, the systematic errors must be evaluated, which requires an implementation of a numerical model encompassing various physical phenomena.

In this paper, a developed numerical model is presented, which was used to solve a transient fluid-structure interaction (FSI) problem of the pulsatile blood flow in a straight, physically meaningful anisotropic, hyperelastic OA, with ICP and external pressure $(\mathrm{Pe})$ loads.

It was found that the systematic error based on mean cross-sectional area difference between IOA and EOA segments was $\{-1.48,-1.37,-1.17\} \mathrm{mmHg}$ with $I C P=\{10,20,30\} \mathrm{mmHg}$, respectively. The systematic error based on mean blood flow velocity difference between IOA and EOA segments was $\{-1.84$, $-1.76,-1.625\} \mathrm{mmHg}$ with $I C P=\{10,20,30\} \mathrm{mmHg}$, respectively.

The presented numerical model examined the worst-case scenario in terms of boundary conditions, which were immovable, while lengths of OA segments were physiologically relevant statistical means; however, the obtained systematic errors still met the clinical standards of ANSI/AAMI, where it is stated that the error should not exceed the $\pm 2 \mathrm{mmHg}$ in the range of $0-20 \mathrm{mmHg}$ of ICP. Boundary conditions and compliance affects the systematic error in both ways (reduce or increase it); this may explain the low systematic errors obtained in experimental studies by other authors.

Keywords: intracranial pressure, non-invasive, balance state, ophthalmic artery, fluid-structure interaction 


\section{INTRODUCTION}

Severe traumatic brain injuries (TBI) are one of the leading causes of disability and death worldwide [1]. Clinically, only the secondary brain damage can be prevented, as the only prevention of primary cause is higher self-awareness. Secondary brain damage occurs when autoregulatory mechanisms fails to drain the cerebrospinal fluid (CSF) and venous blood from the intracranial compartment [2]. Consequently, as the skull is a rigid structure, any additional increase in intracranial constituent (e.g. arterial blood volume) leads to exponential increase in intracranial pressure $(I C P)$ [2], which if not clinically addressed, leads to the secondary brain damage.

In case of TBI, monitoring of ICP can be used for secondary brain damage prevention [3]. Recently, safe non-invasive ICP measurement methods are being developed, as the invasive monitoring methods pose a risk of complications [4]. One of the promising non-invasive ICP measurement method [5] postulates the existence of the pressure balance state at which $I C P=P e$, where $P e$ is the artificially added external pressure.

The existence of the pressure balance state is driven by the unique OA morphological property [6]; assessed clinical research on human OA shows that in general OA crosses several different segments: intracranial ophthalmic artery segment (IOA), which is inside the skull and is affected by the ICP, optic canal segment (OC) and extracranial segment (EOA), which is in the eye socket [7] and can be affected by the additional external pressure $P e$ (Fig. 1). During non-invasive ICP measurement, blood flow velocity or cross-sectional area can be monitored simultaneously at IOA and EOA segments, while external pressure $P e$ is increased by a smooth step function. The accuracy of the ICP measurement is the key parameter allowing a safer non-invasive method to be widely accepted and used in a clinical practice routinely.

Measurement accuracy can be decoupled into the systematic error and random error. Assessed clinical research [8] showed a strong correlation between the lumbar puncture CSF pressure and noninvasively measured $I C P$ with the mean systematic error of $0.12 \mathrm{mmHg}$ and the random error of $2.19 \mathrm{mmHg}$. However, fundamental understanding about the blood flow dynamics in elastic arteries during non-invasive ICP measurement is needed in search of the optimal measurement strategy allowing to increase the ICP measurement accuracy.

Experiments in vivo are not always possible, and therefore numerical modeling can be used as a substitutional method. The numerical results of the blood flow velocity and pressure waveforms in the one-dimensional, reconstructed, rigid OA was validated against the clinical measurements and it was shown that the model can aid in terms of a better clinical decision making [7]. The numerical simulation of a one-dimensional, straight, elastic OA [9] showed that the pressure balance state is independent of the changing

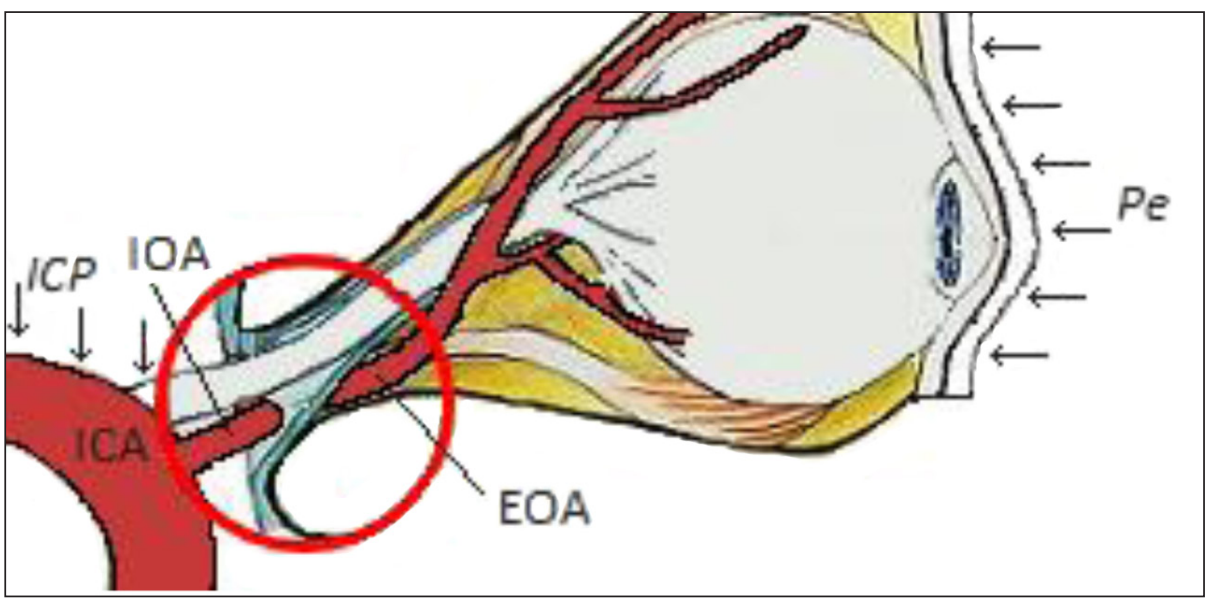

Fig. 1. Intracranial pressure measurement scheme. Red circle shows the area of focus of the current research 
vascular resistance, and the predicted systematic error was within the limits $\{-3.0,+1.0\} \mathrm{mmHg}$ with ICP values between $\{10,40\} \mathrm{mmHg}$. The effects on systematic errors of ICP evaluation were analyzed in [10] were it was found that non-symmetrical boundary conditions affect the value of systematic errors. The transient three-dimensional numerical model of a straight internal carotid artery (ICA) and OA system, incorporating the isotropic hyperelastic artery wall of a non-zero width and blood flow interaction, was used to evaluate the pressure balance state based on the blood flow and artery characteristics [11]. The results of the numerical model [11] showed that the systematic error was composed of arterial pressure difference between IOA and EOA segments, boundary condition asymmetries and an additional pressure balance term, which was postulated to exist due to transient blood flow rate differences between IOA and EOA segments, which can be referenced as a compliance of the artery in the region between measurement locations. However, due to limited computational resources the model was limited to only one $I C P$ value of $10 \mathrm{mmHg}$.

Here we present a numerical model of a pulsatile blood flow in a compliant OA and an investigation of a worst-case scenario in terms of boundary conditions, which were prescribed to be immovable, at the internal carotid ophthalmic arteries bifurcation site and optic canal. We performed the investigation with an extended set of $I C P$ values $\{0,10,20,30\} \mathrm{mmHg}$ and also used a physically motivated phenomenological HGO constitutive arterial wall model, which to a great extent can reproduce the empirical results of a passive artery wall behavior [12]. The main goal was to investigate the systematic errors based on blood flow velocity and cross-sectional area differences between measurement locations.

\section{NUMERICAL METHODS}

We assume that the non-invasive ICP measuring apparatus (Fig. 1) can be made perfectly accurate, in a sense that fundamental blood flow dynamics and human physiology are the driving causes of the technical characteristics of the apparatus, and here we only focus on the ophthalmic arte- ry and external stimuli (Fig. 1). We assume that the external pressure $P e$ applied by the apparatus is homogenous throughout the eye socket. Additionally, we assume that intracranial pressure ICP is also homogenous inside the skull and that any external stimuli imitated by the boundary conditions are also homogenous. Based on our investigation focus and made assumptions, the main model domains are the artery wall, blood and boundary conditions imitating the external stimulus.

A problem of pulsating blood flow in a compliant artery falls under the category of more general fluid-structure interaction (FSI) problems. These problems include continuous bodies, for which the fundamental classical conservation laws defining their temporal behavior are described by the continuum mechanics [13]. In continuum mechanics, conservation laws are defined by partial differential equations, which can be solved using numerical procedures, of which the finite element method was used.

FSI problems are solved using the so-called arbitrary Lagrangian-Eulerian (ALE) formulation, which is usually used for the fluid domain. ALE takes advantage of both the Eulerian (spatial) formulation, enabling to solve large deformations and Lagrangian (material) formulation, enabling to track the moving interphase boundary, by introducing the third arbitrary (mesh) formulation.

\section{ALE formulation for the blood domain}

Naturally, fluid is formulated in Eulerian description. It could be thought as if the observer is watching the flow from a fixed point. The Lagrangian formulation is usually used when dealing with a solid material. This can be though as if the observer is moving together with the material point. The main complexity arises when solid and fluid domains are interacting through the common boundary. Notably, ALE formulation is reliable and is applied as a framework to solve various FSI problems $[14,15]$. In the ALE formulation several configurations are defined, as shown in Fig. 2.

The position vector of spatial, material and mesh configurations is denoted by $\mathbf{x}, \mathbf{X}$ and $\chi$, respectively. All three configurations coincide at time $t=0$. 


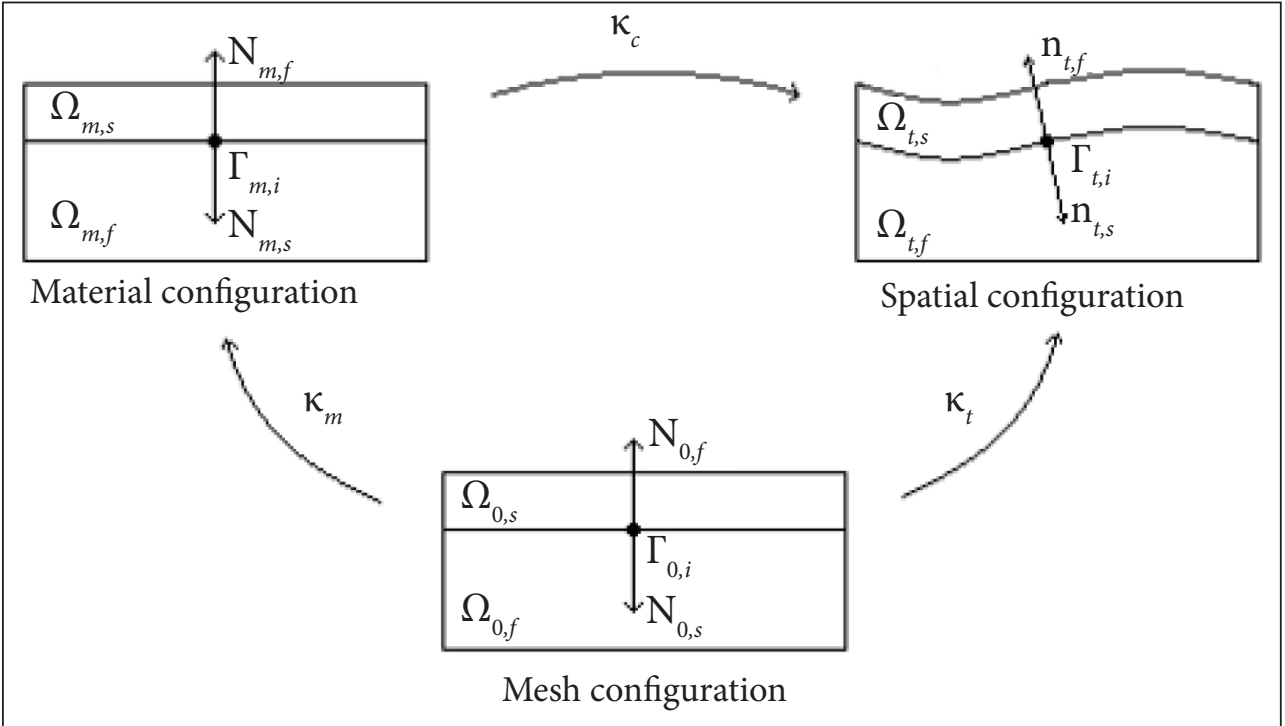

Fig. 2. Different configurations used in the ALE framework

The mapping from the mesh domain to the material domain is made by $\mathbf{X}=\boldsymbol{\kappa}_{m}(\chi, t)$ map, and the mesh motion is mapped to the spatial domain by $\mathbf{x}=\boldsymbol{\kappa}_{t}(\chi, t)$ map. The mapping from the material domain to the spatial domain is performed via $\mathbf{x}=\boldsymbol{\kappa}_{c}(\chi, t)$ map.

\section{Displacement and deformation measures}

The displacement field can be represented by the vector field in the material configuration as follows [13]:

$$
\mathbf{U}(\mathbf{X}, t)=\mathbf{x}(\mathbf{X}, t)-\mathbf{X} .
$$

The displacement field in the spatial configuration is as follows [13]:

$$
\mathbf{u}(\mathbf{x}, t)=\mathbf{x}-\mathbf{X}(\mathbf{x}, t) .
$$

Both displacement field configurations are related by the inverse map as follows [13]:

$$
\mathbf{U}(\mathbf{X}, t)=\mathbf{U}\left(\boldsymbol{\kappa}_{c}^{-1}(\mathbf{x}, t), t\right)=\mathbf{u}(\mathbf{x}, t) .
$$

Based on eq. (3), the displacement field in the material configuration and in the spatial configuration is equal and therefore can be substituted in equations in case the need arises.

The deformation gradient tensor $\mathbf{F}$ relates the position vector $\mathbf{X}$ in the material configuration to the point $x$ in the spatial configuration as follows $[13,16]$ :

$$
\mathbf{F}(\mathbf{X}, t)=\frac{\partial \mathbf{x}}{\partial \mathbf{X}}=\mathbf{I}+\frac{\partial \mathbf{u}}{\partial \mathbf{X}},
$$

where $\mathbf{I}$ is the identity matrix. The right Cauchy-Green tensor is $\mathbf{C}=\mathbf{F}^{\mathrm{T}} \mathbf{F}$, in case of isochoric and volumetric split the isochoric deformation gradient with omitted variables in brackets is $\overline{\mathbf{F}}=\left(J^{-1 / 3} \mathbf{I}\right) \mathbf{F}$, where $J=\operatorname{det}(\mathbf{F})$ is the Jacobian determinant. Isochoric right Cauchy-Green tensor is $\overline{\mathbf{C}}=\overline{\mathbf{F}}^{\mathrm{T}} \overline{\mathbf{F}}$.

\section{Governing equations for the artery wall in material configuration}

The mass conservation equation is usually not solved for the solid domain [17] (in this case the artery wall domain), because elastic deformations have a relatively little effect on the change in the material volume, while plastic deformations even preserve the material volume and therefore the change in density is also relatively small or negligible, meaning that the mass is conserved in either case.

The equation of motion for the artery wall [13] with omitted volumetric forces (e.g. gravity) is as follows:

$$
\rho_{s} \frac{\partial^{2} \mathbf{u}_{s}}{\partial t^{2}}=\operatorname{Div} \mathbf{P}
$$

where $\rho_{s}$ is the artery wall density, $t$ is the time, Div is the divergence operator in the material configuration, $\mathbf{u}_{s}$ is the displacement of the artery 
wall, which was used instead of $\mathbf{U}_{s}$ due to the equality shown in eq. (3), $\mathbf{P}$ is the first Piola-Kirchhoff stress tensor.

The artery wall was assumed to act as a hyperelastic material, and for a hyperelastic material $\mathbf{P}=\partial \Psi / \partial \mathbf{F}$, where $\Psi$ is the strain energy function, defined by the material constitutive equation.

The Cauchy stress tensor $\boldsymbol{\sigma}_{s}$ for the artery wall is calculated based on the Nanson's formula [13] as follows:

$$
\boldsymbol{\sigma}_{s}=J^{-1} \mathbf{P F}^{\mathrm{T}}
$$

The boundary conditions for the artery wall in the general form are as follows [18]:

$$
\begin{aligned}
& \mathbf{u}_{s}=\mathbf{u}_{s}{ }^{\mathrm{D}}, \\
& \mathbf{P N}=\mathbf{G}_{s},
\end{aligned}
$$

where $\mathbf{u}_{s}{ }^{\mathrm{D}}$ is the displacement prescribed at the $\mathrm{Di}$ richlet boundary, $\mathbf{N}$ is the unit normal vector in the material configuration pointing outward from the artery wall, $\mathbf{G}_{s}$ is the first Piola-Kirchoff stress tensor prescribed at the Neumann boundary.

\section{Governing equations for the blood flow based on ALE formulation}

It was assumed that blood is incompressible fluid, which is justified by a relatively low blood flow velocity in the ophthalmic artery compared with the speed of sound in blood. Also, the blood was assumed to be homogenous and the density was assumed to be constant through the ophthalmic artery. Based on these assumptions the mass conservation equation for the fluid (blood) then becomes as follows [13]:

$$
\operatorname{divv}_{f}=0,
$$

where is the divergence operator in spatial configuration, $\mathbf{v}_{f}$ is the blood velocity.

The momentum conservation equation for the fluid (blood) with omitted volumetric forces (e.g. gravity) based on the ALE formulation is as follows [18]:

$$
\rho_{f}\left(\left.\frac{\partial \mathbf{v}_{f}}{\partial t}\right|_{\mathbf{x}}+(\mathbf{c} \cdot \nabla) \mathbf{v}_{f}\right)=-\operatorname{div} \boldsymbol{\sigma}_{f}
$$

where $\rho_{f}$ is the blood density, $\mathbf{c}$ is the convective velocity defined as the difference between the material and mesh velocities, and $\boldsymbol{\sigma}_{f}$ is the Cauchy stress tensor for blood. The Cauchy stress tensor for an incompressible fluid (blood) is as follows [18]:

$$
\boldsymbol{\sigma}_{f}=-p_{f} \mathbf{I}+\mu_{f}\left(\nabla \mathbf{v}_{f}+\left(\nabla \mathbf{v}_{f}\right)^{\mathrm{T}}\right),
$$

where $p_{f}$ is the arterial blood pressure, $\mathbf{I}$ is the identity matrix, $\mu_{f}$ is the blood dynamic viscosity. It was assumed that blood is a Newtonian fluid and therefore the effective blood dynamic viscosity $\mu_{f}$ is constant. The assumption of Newtonian fluid is justified by the fact that the Newtonian shear rate model can accurately capture the blood flow behavior in arteries, of which lumen diameter is larger or close to $1 \mathrm{~mm}$ [19], such as OA, in which the shear rate of blood is always higher than $100 \mathrm{~s}^{-1}$.

The boundary conditions for the blood in the general form are as follows [18]:

$$
\begin{aligned}
& \mathbf{v}_{f}=\mathbf{v}_{f}^{\mathrm{D}}, \\
& -\boldsymbol{\sigma} \mathbf{n}_{f}=\mathbf{g}_{\rho}
\end{aligned}
$$

where $\mathbf{v}_{f}^{\mathrm{D}}$ is prescribed blood velocity at the Dirichlet boundary, $\boldsymbol{\sigma}$ is the Cauchy stress tensor, $\mathbf{n}_{f}$ is the unit normal vector pointing outward from the blood domain, $\mathbf{g}_{f}$ is the prescribed Cauchy stress tensor at the Neumann boundary.

\section{Constitutive fiber-reinforced material model for artery wall}

A healthy artery wall is composed of several layers: tunica intima, tunica media and tunica adventitia [20]. Tunica intima is the innermost layer, which is in direct contact with the blood. Usually, in a healthy artery it has a negligible effect on the artery mechanical behavior [21]. Tunica media is the middle layer, which is mainly composed of smooth muscle cells, collagen and elastin fibers. Tunica adventitia is the outermost layer, of which the main component is the collagen fibers. Due to collagen fibers in the layers of tunica media and tunica adventitia the artery is anisotropic (transversely isotropic) and a strong stiffening effect is common when the inner pressure is relatively high. In any artery layer, two families of fibers exist, that are in symmetrical configuration with circumferential direction. Based on experimental evidence it was 
widely accepted that the artery wall is incompressible [22]; however, newer findings challenge this assumption [23, 24]. Most of the constitutive models of the artery wall were developed in regards with the incompressible assumption, and only the newest constitutive models and numerical schemes tried to incorporate compressibility and inextensibility [25]. Here we use the constitutive model based on the previously widely accepted incompressibility assumption.

Numerical difficulties, called locking phenomena [26], arise when the material is prescribed as nearly incompressible. To resolve these difficulties, a mixed finite element formulation is introduced, in which it is common to implement the decoupled form of the strain energy function [18]. For a homogenous material with two families of fibers, a decoupled strain energy function developed by [21] is given in the following form:

$$
\Psi=\bar{\Psi}_{g}\left(\bar{I}_{1}\right)+\bar{\Psi}_{f}\left(\bar{I}_{4}, \bar{I}_{6}\right)+\Psi_{v o l}(J),
$$

where $\bar{\Psi}_{g}\left(\bar{I}_{1}\right)$ captures the isochoric part of isotropic ground structure and $\bar{\Psi}_{f}\left(\bar{I}_{4}, \bar{I}_{6}\right)$ captures the isochoric part of anisotropic fiber structure, while $\Psi_{v o l}(J)$ defines the volumetric strain energy density and resolves nearly incompressibility, $\bar{I}_{1}$ represents the isochoric, isotropic stretch (independent of direction), $\bar{I}_{4}$ and $\bar{I}_{6}$ represent the isochoric square of the stretch in the direction of the first and second family of fibers, respectively. the invariants $\bar{I}_{1}, \bar{I}_{4}, \bar{I}_{6}$ are as follows [21]:

$$
\bar{I}_{1}=\operatorname{tr} \overline{\mathbf{C}}, \bar{I}_{4}=\mathbf{M}_{j 1} \cdot \overline{\mathbf{C}} \mathbf{M}_{j 1}, \bar{I}_{6}=\mathbf{M}_{j 2} \cdot \overline{\mathbf{C}} \mathbf{M}_{j 2},
$$

where $j=\{$ media, adventitia $\}, \mathbf{M}_{j 1}$ is a tensor characterizing the first family fibers of the $j$-th artery wall layer, $\mathbf{M}_{j 2}$ is a tensor characterizing the second family fibers of the $j$-th artery wall layer. $\mathbf{M}_{j 1}=\mathbf{m}_{j 1} \otimes \mathbf{m}_{j 1}$ and $\mathbf{M}_{j 2}=\mathbf{m}_{j 2} \otimes \mathbf{m}_{j 2}$, where $\mathbf{m}_{j 1}$ is the $j$-th artery wall first fiber family direction vector, $\mathbf{m}_{j 2}$ is the $j$-th artery wall second fiber family direction vector. Fiber direction defining vectors are in material configuration.

Based on [21], the isotropic response is governed by the neo-Hookean model, and anisotropic response of fiber structure is governed by the Fung-type exponential model. Then the strain energy function for the fiber-reinforced material is as follows:

$$
\Psi=\frac{1}{2} \mu\left(\bar{I}_{1}-3\right)+\frac{k_{1}}{2 k_{2}} \sum_{i=4,6}\left\{e^{k_{2}\left(\bar{I}_{i}-1\right)^{2}}-1\right\}+\frac{\kappa}{2}(J-1)^{2},(16)
$$

where $k_{1}, k_{2}$ are empirical positive material constants, $\kappa$ is initial bulk modulus, $\mu$ is the shear modulus, and $i=\{4,6\}$.

\section{Definition of fiber directions}

In order to consider the anisotropy of the artery wall material, fiber directions must be defined at every point of the artery wall. To simplify the definition of fiber directions, the wall of the artery can be described with a reference to a cylindrical coordinate system consisting of three unit vectors $\mathbf{R}, \boldsymbol{\theta}, \mathbf{z}$, prescribing radial, circumferential and axial directions, respectively. In the material configuration, fiber directions of two families in two different layers $j=1,2$ are defined by unit vectors $\mathbf{m}_{j 1}$ and $\mathbf{m}_{j 2}$ that are in constant angles $\pm \beta$ with circumferential direction, and they lie in a plane that is normal to the surface of an artery. In this case unit vectors $\mathbf{m}_{j 1}$ and $\mathbf{m}_{j 2}$, with respect to the cylindrical coordinate system $\mathbf{R}, \boldsymbol{\theta}, \mathbf{z}$, are as follows [21]:

$$
\begin{gathered}
\mathbf{m}_{j 1}=\left[\begin{array}{c}
0 \\
\cos (\beta) \\
\sin (\beta)
\end{array}\right], \\
\mathbf{m}_{j 2}=\left[\begin{array}{c}
0 \\
\cos (\beta) \\
-\sin (\beta)
\end{array}\right] .
\end{gathered}
$$

The interaction between blood and artery wall happens at the coupling interface boundary. ALE formulation is used to describe the deformations of the blood domain [27]. Total surface force $\mathbf{f}_{f}=\mathbf{n}_{f} \boldsymbol{\sigma}_{f}$ exerted by the blood on the boundary of the artery wall is equal to the negative reaction force $\mathbf{f}_{s}=-\mathbf{n}_{s} \boldsymbol{\sigma}_{s}$, which is exerted on the blood. The coupling on the interface boundary is then calculated as follows [18]:

$$
\mathbf{n}_{s} \boldsymbol{\sigma}_{s}+\mathbf{n}_{f} \boldsymbol{\sigma}_{f}=0,
$$

where $\mathbf{n}_{s}$ is the unit normal pointing outwards from the artery wall boundary. Blood domain is affected by a moving artery wall through the structural velocities calculated as follows [18]: 


$$
\mathbf{v}_{f}=\mathbf{v}_{s}=\frac{\partial \mathbf{u}_{s}}{\partial t},
$$

where $\mathbf{v}_{s}$ is the wall velocity.

\section{FSI model parameters}

Parameters presented in Tables 1-3 are used to define the basic material properties of the blood, artery wall, and of the simulation process.

Table 1. Basic material parameters

\begin{tabular}{|c|c|c|c|}
\hline Blood parameter & Notation & Value & Units \\
\hline $\begin{array}{c}\text { Dynamic viscosity } \\
{[28]}\end{array}$ & $\mu_{f}$ & 0.003675 & $\mathrm{~kg} \cdot \mathrm{m}^{-1} \cdot \mathrm{s}^{-1}$ \\
\hline Density [29] & $\rho_{f}$ & 1060 & $\mathrm{~kg} \cdot \mathrm{m}^{-3}$ \\
\hline Artery wall parameter & Notation & Value & Units \\
\hline Density [30] & $\mathrm{P}_{s}$ & 1100 & $\mathrm{~kg} \cdot \mathrm{m}^{-3}$ \\
\hline
\end{tabular}

Table 2. Geometry parameters

\begin{tabular}{ccccc}
\hline Geometry parameters & Notation & Value & Units \\
\hline Initial lumen diameter & $d_{\text {init }}$ & 1.3 & $\mathrm{~mm}$ \\
\hline Length of OA [31] & $L$ & 25.783 & $\mathrm{~mm}$ \\
\hline Length of $\Gamma_{1}(\mathrm{IOA})[31]$ & $L_{\Gamma 1}$ & 4.116 & $\mathrm{~mm}$ \\
\hline Length of $\Gamma_{5}(\mathrm{OC})[32]$ & $L_{\Gamma 5}$ & 12 & $\mathrm{~mm}$ \\
\hline Length of $\Gamma_{2}$ (EOA) [31] & $L_{\Gamma 2}$ & 9.667 & $\mathrm{~mm}$ \\
\hline Wall thickness [33] & $h$ & 0.177 & $\mathrm{~mm}$ \\
\hline
\end{tabular}

\section{Solver properties}

The COMSOL Multiphysics software, which is based on implementation of the finite element method, was used to perform numerical modeling. PARDISO (Parallel sparse direct linear system solver), in conjunction with a nonlinear fully coupled damped-Newton method together with the time stepping generalized- $\alpha$, was used as a solver. The damping factor for a nonlinear Newton method was set to a constant value of 1 and the Jacobian update was set to minimal (reuse the Jacobian for several nonlinear systems whenever deemed possible). Absolute tolerance for all variables: pressure, auxiliary pressure, displacement field, velocity field, spatial coordinates was set to $5 \cdot 10^{-4}$, while the maximum time step size was set to $0.004 \mathrm{~s}$. At times when gradients were relatively high, to resolve study on such tolerances, the time step size automatically decreased down to a value of $10^{-6} \mathrm{~s}$ to resolve high gradients.

\section{RESULTS AND DISCUSSION}

\section{Model setup and boundary conditions}

OA geometry was composed of a blood domain $\Omega_{\text {blood }}$ and two OA wall domains: $\Omega_{\text {media }}$ and $\Omega_{\text {adventitia }}$ shown in Fig. 3. Parameters defining

Table 3. Simulation parameters

\begin{tabular}{|c|c|c|c|}
\hline Simulation parameters & Notation & Value & Units \\
\hline Duration of one time period [34] & $T$ & 1 & s \\
\hline Duration of initialization & $t_{\text {init }}$ & 1 & s \\
\hline Duration of $P e=$ const & $t_{c}$ & 2 & s \\
\hline Duration of Pe loop & $t_{P}$ & 3 & s \\
\hline Peak value of velocity profile max. of one time period & $u_{\text {maxpeak }}$ & 56.48 & $\mathrm{~cm} / \mathrm{s}$ \\
\hline Surface averaged value of velocity profile max. of time period & $u_{\text {max mean }}$ & 28.24 & $\mathrm{~cm} / \mathrm{s}$ \\
\hline Peak value of velocity profile min. of time period & $u_{\text {minpeak }}$ & 12.28 & $\mathrm{~cm} / \mathrm{s}$ \\
\hline Surface averaged value of velocity profile min. of time period & $u_{\text {min mean }}$ & 6.14 & $\mathrm{~cm} / \mathrm{s}$ \\
\hline Max. pressure of time period [35] & $P_{\text {sys }}$ & 80 & $\mathrm{mmHg}$ \\
\hline Min. pressure of time period [35] & $P_{\text {dias }}$ & 40 & $\mathrm{mmHg}$ \\
\hline Magnitude of increase in $I C P_{1, i}$ & $S_{I C P}$ & 10 & $\mathrm{mmHg}$ \\
\hline Amplitude of $I C P_{i}$ (function of $i$ ) & \multicolumn{2}{|c|}{$A_{I C P}=S_{I C P}(i-1)$} & $\mathrm{mmHg}$ \\
\hline Amplitude of $P e$ & $A_{P e}$ & 38 & $\mathrm{mmHg}$ \\
\hline Magnitude of increase in $\mathrm{Pe}$ & $S_{P e}$ & 2 & $\mathrm{mmHg}$ \\
\hline Distance from OA starting location at which data was collected at IOA segment & $L_{c, 1 O A}$ & 2.058 & $\mathrm{~mm}$ \\
\hline Distance from OA starting location at which data was collected at EOA segment & $L_{c, E O A}$ & 20.834 & $\mathrm{~mm}$ \\
\hline
\end{tabular}




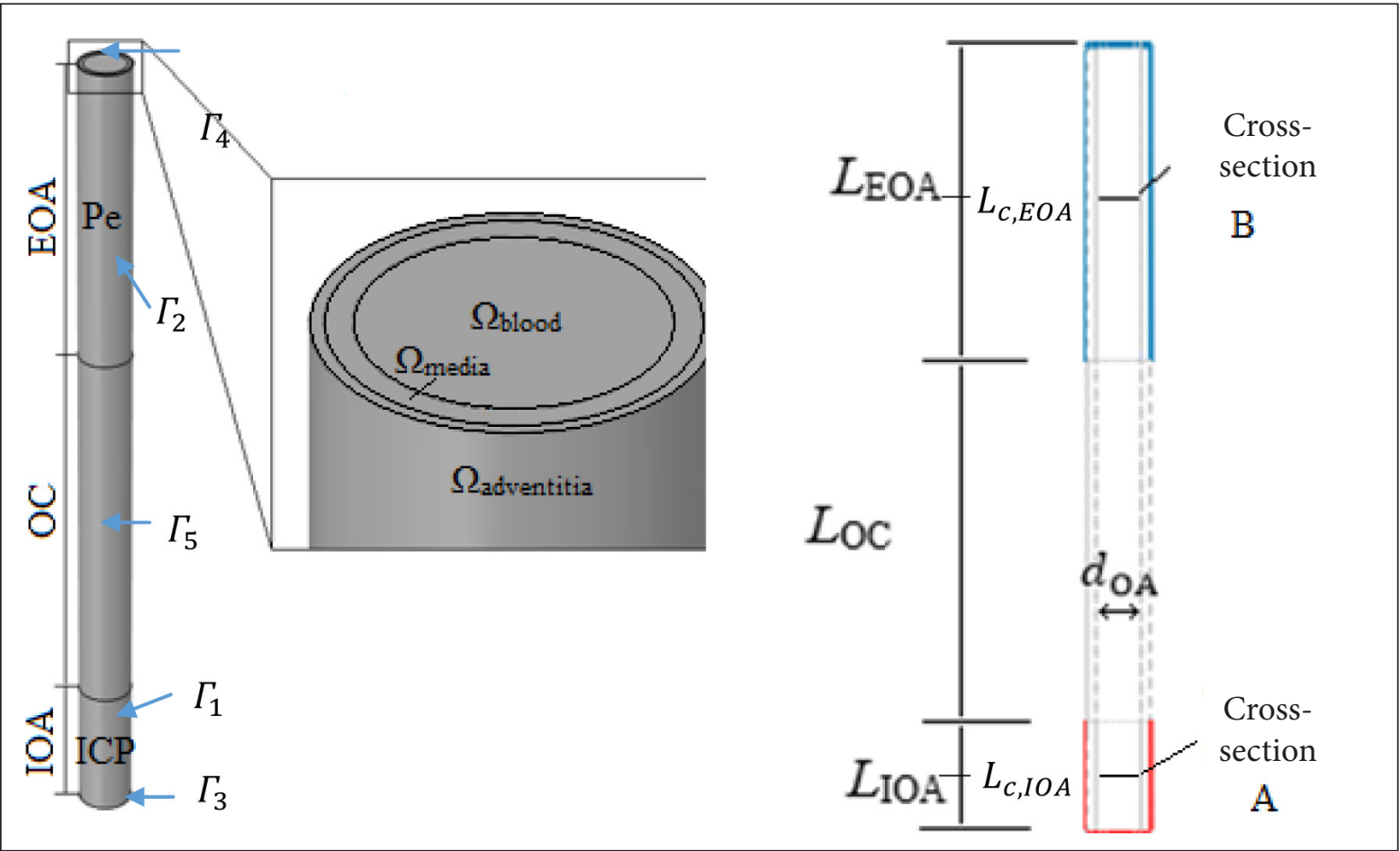

Fig. 3. The $O A$ model geometry with depicted $I O A, O C, E O A$ segments, blood and $O A$ media and adventitia layer domains, boundaries of acting pressures $P$ e and I $C P$ together with a cross-sectional scheme of $O A$ and lines representing $A$ and $B$ cross-sections where the data was collected at the distances $L_{C, I O A}$ and $L_{C, E O A^{\prime}}$ respectively

the basic material properties of the blood, and of the OA wall are given in Table 1. As the data of additional parameters required by the constitutive material model for the OA wall, are scarce in the scientific literature, ICA parameters were used instead (provided in Table 4).

Table 4. OA wall parameters used for fiber-reinforced double layer model based on ICA wall parameters according to [12]

\begin{tabular}{ccc}
\hline Arterial wall parameters & Adventitia & Media \\
\hline Isotropic, $c_{10}, \mathrm{kPa}$ & 28.3 & 17.6 \\
\hline Anisotropic, $k_{1}, \mathrm{kPa}$ & 112.1 & 21.3 \\
\hline Anisotropic, $k_{2}$ & 100.6 & 17.3 \\
\hline Fiber angle, $\beta, \mathrm{deg}$ & 31.8 & 9.8 \\
\hline
\end{tabular}

Structural information consisting of the wall thickness of OA, the internal vessel diameter, the length of the vessel and the lengths of IOA, OC, and EOA segments are provided in Table 2.

ICP was prescribed as a Neumann boundary condition based on eqs. (8) and (6) as a function dependent on time $I C P_{i}(t)$ acting on the outside surface of IOA wall segment $\Gamma_{1}$ as follows:

$$
I C P_{i}=A_{I C P}(i)\left\{\begin{array}{c}
\frac{t}{t_{\text {init }}}, \mid t<t_{\text {init }} \\
1, \mid t \geq t_{\text {init }}
\end{array} .\right.
$$

For a healthy adult in the supine position, the normal ICP range is between $7 \mathrm{mmHg}$ and $15 \mathrm{mmHg}$ [36], for children between $3 \mathrm{mmHg}$ and $7 \mathrm{mmHg}$, for term infants from $2 \mathrm{mmHg}$ and $6 \mathrm{mmHg}$, and for pathological patients, ICP can exceed $25 \mathrm{mmHg}$ [37]. Aforementioned ICP values motivated us to set ICP lower limit to $0 \mathrm{mmHg}$ and upper limit to $30 \mathrm{mmHg}$, and the set of ICP amplitude values was $A_{I C P}(i)=\{0,10,20,30\} \mathrm{mmHg}$ for $i=1,2,3,4$.

$P e$ was prescribed as a Neumann boundary condition based on eqs. (8) and (6) as a function dependent on time $P e(t)$ acting on the outside surface of EOA wall segment $\Gamma_{2}$ as follows:

$$
P e=\left\{\begin{array}{r}
P e_{b}, \mid t>t_{\text {init }}, \\
0, \mid t \leq t_{\text {init }}
\end{array}\right.
$$


where $P e_{b}$ was prescribed as follows:

$$
\begin{aligned}
& P e_{b}=s_{P e}\left\{\begin{array}{r}
\frac{t-\text { floor }\left(\frac{t}{t_{P}}\right) t_{P}}{T}+\text { floor }\left(\frac{t}{t_{P}}\right)-1, \\
\text { ceil }\left(\frac{t-t_{P}}{t_{P}}\right), \\
t-\text { floor }\left(\frac{t}{t_{P}}\right) t_{P}<T \\
t-\text { floor }\left(\frac{t}{t_{P}}\right) t_{P} \geq T
\end{array}\right.
\end{aligned}
$$

Boundaries $\Gamma_{3}, \Gamma_{4}, \Gamma_{5}$ were prescribed to be immovable based on the Dirichlet boundary condition (eq. (7)) and artery wall was prescribed to only allow the expansion and contraction and no twisting or bending was permitted.

The laminar inflow boundary condition based on the Neumann boundary condition (eq. (13)) was prescribed as a pressure function $P_{i n}(t)$ acting on the surface of OA blood domain inlet. It was used to start the blood flow as fully developed at the inlet and was prescribed as follows:

$$
P_{\text {in }}=\left\{\begin{array}{c}
\frac{P_{\text {dias }} t}{t_{\text {init }}}, \mid t<t_{\text {init }}, \\
P_{v}, \mid t \geq t_{\text {init }}
\end{array}\right.
$$

where $P_{v}$ waveform was similar to $v_{\text {in }}$ waveform provided in Fig. 4 with a difference in amplitude where $P_{\text {sys }}$ was pressure value at the systole and $P_{\text {dias }}$ was pressure at the diastole.

The laminar outflow boundary condition based on the Neumann boundary condition (eq. (13)) was prescribed as a pressure function $P_{\text {out }}(t)$ acting on the surface of OA blood domain

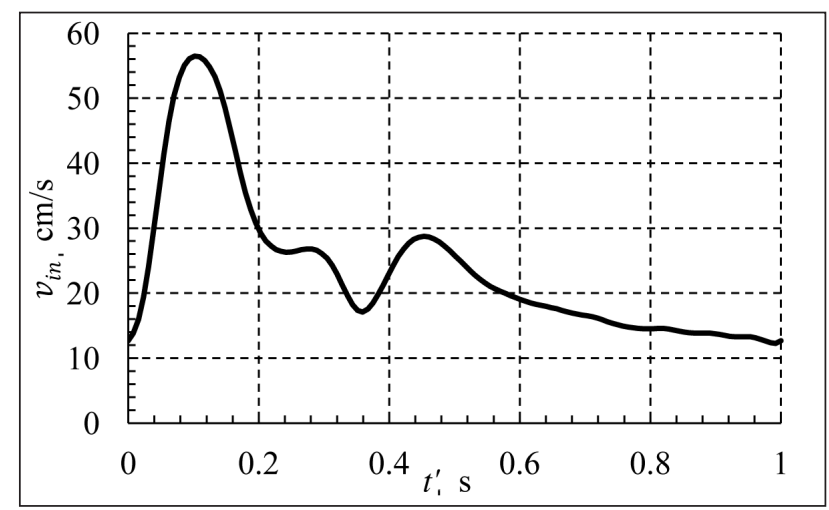

outlet. It was used to define the constant pressure $P_{\text {out }}$ at distance $L_{\text {exit }}$ as follows:

$$
P_{\text {out }}=\left\{\begin{array}{c}
\frac{P_{\text {dist }} t}{t_{\text {init }}}, \mid t<t_{\text {init }} \\
P_{\text {dist }}, \mid t \geq t_{\text {init }}
\end{array} .\right.
$$

A combination of variable inlet pressure $P_{\text {in }}$ and constant outlet pressure $P_{\text {dist }}=70.15 \mathrm{mmHg}$ (eq. (27)) at the analytically calculated distance $L_{\text {exit }}=25.63 \mathrm{~cm}$ (eq. (26)), based on the Hagen-Poiseuille equation generated a uniform waveform of blood pressure and blood velocity and generated $v_{\text {in }}$ according to Fig. 4 .

$$
\begin{gathered}
P_{\text {dist }}=P_{s y s}-\frac{u_{\text {max }_{\text {mean }}}\left(P_{s y s}-P_{\text {dias }}\right)}{\left(u_{\text {max }_{\text {mean }}}-u_{\text {min }_{\text {mean }}}\right)}, \\
P_{\text {dist }}=P_{s y s}-\frac{u_{\text {max }_{\text {mean }}}\left(P_{s y s}-P_{\text {dias }}\right)}{\left(u_{\text {max }_{\text {mean }}}-u_{\text {min }_{\text {mean }}}\right)} .
\end{gathered}
$$

Based on [11], the geometry was discretized into 71644 finite elements, with 49734 elements for blood domain, 13506 elements for tunica media domain, and 8404 elements for tunica adventitia domain.

\section{Analysis of simulation results}

In total, $N \cdot 60$ time periods were modeled, where $N=4$ is the number of simulations and $i=\overline{1: \mathrm{N}}$ is study index/number. First time period was used to initialize the simulation by gradually increasing inlet pressure $P_{\text {in }}$ from $0 \mathrm{mmHg}$ to $40 \mathrm{mmHg}$, outlet pressure $P_{\text {out }}^{\text {in }}$ from $0 \mathrm{mmHg}$ to $P_{\text {dist }}$ and $I C P_{i}$ from $0 \mathrm{mmHg}$ to $\{0,10,20$, $30\} \mathrm{mmHg}$ depending on the study number. After initialization, $I C P_{i}$ was held constant, $P e$ changed according to eq. (22).

Fig. 4. Typical maximum blood flow velocity waveform in $O A$ that was implemented in the numerical model 
Starting from $t=0 \mathrm{~s}$, the data was collected at every time step $t_{s}=0.004$ for all $N \cdot 60$ heartbeat pulse periods. During simulation, blood density and blood dynamic viscosity was constant, while blood velocity and lumen diameter were dynamic parameters. The maximum $R e_{\max }=\rho_{f}\left|\mathbf{v}_{f}\left(t_{s y s}\right)\right| d\left(t_{s y s}\right) / \mu=129$, where $t_{s y s}$ is the time of systole, and minimum $R e_{\text {min }}=\rho_{f}\left|\mathbf{v}_{f}\left(t_{\text {dias }}\right)\right| d\left(t_{\text {dias }}\right) / \mu=24.7$, where $t_{\text {dias }}$ is the time of diastole, Reynolds numbers were calculated from all data points to justify the assumption of laminar blood flow.

From all the data available, only the cross-sectional area $S_{i}(t)$, cross-sectional average blood flow velocity $\left\langle v_{i}(t)\right\rangle$, cross-sectional average arterial blood pressure $\left\langle p_{i}(t)\right\rangle$ were chosen as characteristic parameters at the $\mathrm{A}$ and $\mathrm{B}$ cross-sections (here we denote $i=\{A, B\}$ ) shown in Fig. 3. Here we also denote $t^{\prime}=\bmod (t, T)$, which allows us to compare all heartbeat pulse periods on one time scale and to evaluate the influence of ICP and $P e$. With $t^{\prime}$ introduced, the functional dependence of characteristic parameters becomes as follows: $S_{i}\left(t^{\prime}, I C P, P e\right),\left\langle v_{i}\left(t^{\prime}, I C P, P e\right)>\right.$ and $\left\langle p_{i}(t, I C P, P e)>\right.$. Next we omit the variables in brackets and use only $S_{i},\left\langle v_{i}\right\rangle$ and $\left\langle p_{i}\right\rangle$.

The ICP is determined by comparing the characteristic parameters between $\mathrm{A}$ and $\mathrm{B}$ cross-sections as follows: $\Delta S=S_{A}-S_{B},\langle\Delta v\rangle=\left\langle v_{A}\right\rangle-\left\langle v_{B}\right\rangle$ and $\langle\Delta p\rangle=\left\langle p_{A}\right\rangle-\left\langle p_{B}\right\rangle$.

We selected to perform averaging of characteristic values over one heartbeat pulse period, in this way the dependence on $t^{\prime}$ is eliminated and because in this model the arterial pressure waveform is periodic the dependence on the arterial pressure waveform is also eliminated.

The cross-sectional area difference $\Delta S$ between $A$ and $B$ cross-sections and heartbeat pulse period averaged $\Delta S$, denoted as $\Delta \hat{\mathrm{S}}$, dependence on $t^{\prime}, I C P$ and $P e$ is shown in Fig. 5.

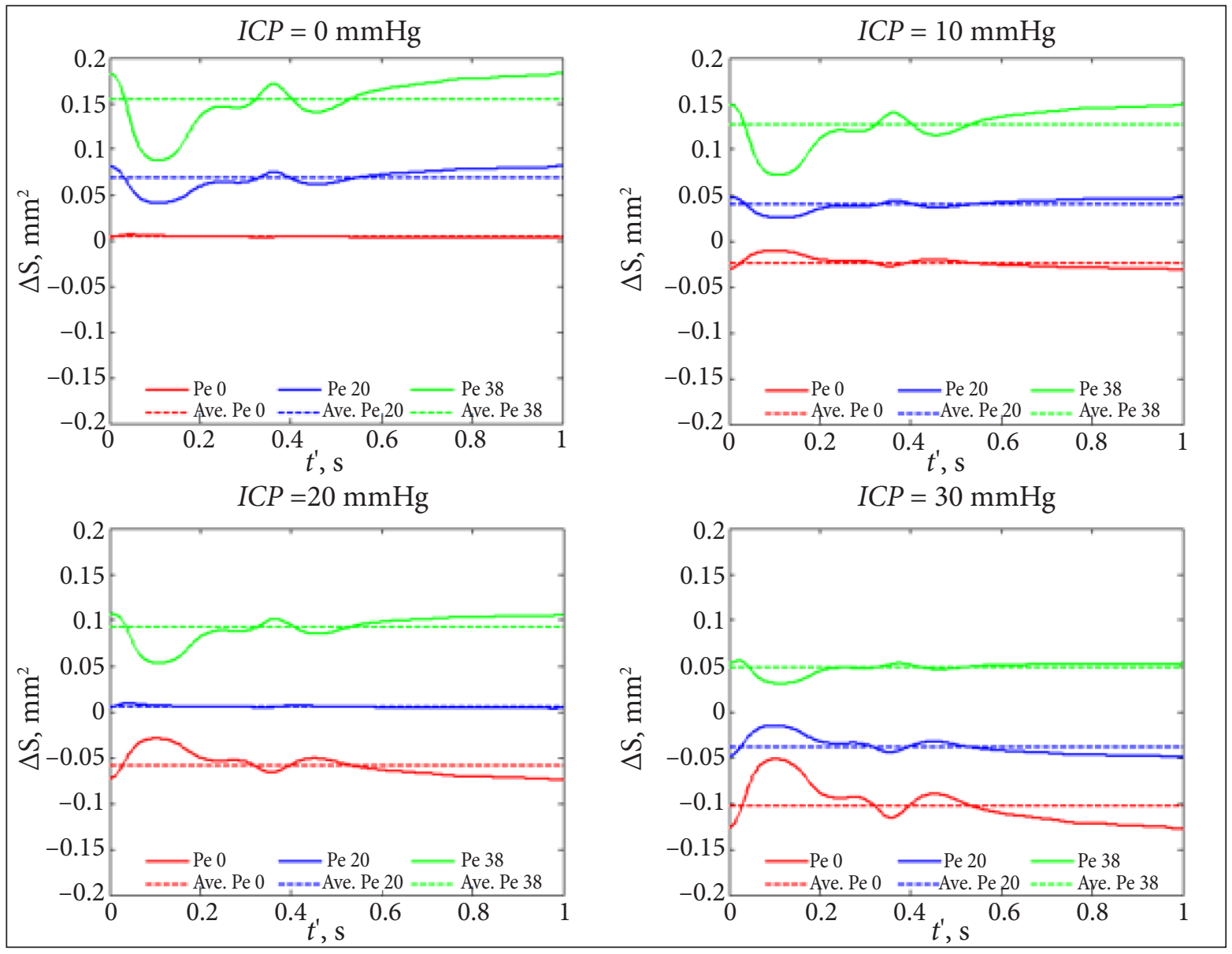

Fig. 5. Cross-sectional area difference between $A$ and $B$ cross-sections, denoted as $\Delta S$, and heartbeat pulse averaged $\Delta S$, denoted as $\Delta \hat{S}$, dependence on $t^{\prime}, I C P$ and $P e$ 
The oscillation of $\Delta S$ about its mean value $\Delta \hat{\mathrm{S}}$ increased with the increase in pressure difference $P e-I C P$ (Fig. 5). When $P e-I C P \rightarrow 0$, then $\Delta S \rightarrow \Delta \hat{\mathrm{S}}$. When the value of $P e-I C P$ becomes close to some specific value, here denoted as inv (in this case inv is close to 0 ), changing the $P e-I C P$ value in the same direction leads to the inversion of $\Delta S$ around the $t^{\prime}$ axis. This means that the oscillation dynamics of $S_{A}$ and $S_{B}$ changes with the change in $P e-I C P$ value. These processes are due to the nonlinear artery wall constitutive model.

A heartbeat pulse averaged difference $\langle\Delta p\rangle$, denoted as $\langle\Delta \dot{p}\rangle$, dependence on the parameters $I C P$ and $P e$ is depicted in Fig. 6. It can be seen that $\langle\Delta \dot{p}\rangle$ changes nonlinearly with respect to $I C P$ and to $P e$. This nonlinear change is due to nonlinear change in $\triangle S$. When $I C P=P e=\{0,10$, $20,30\} \mathrm{mmHg}$, then $\langle\Delta \dot{p}\rangle=\{1.112,1.124,1.141$, $1.164\} \mathrm{mmHg}$.

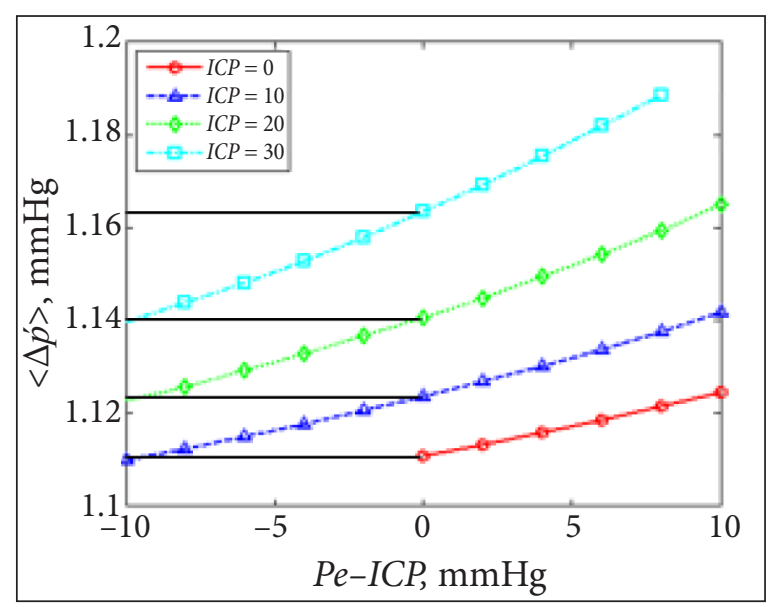

Fig. 6. A heartbeat pulse averaged $\langle\Delta p\rangle$, denoted as $\langle\Delta p \dot{p}\rangle$, dependence on the $I C P$ and $P e$

The cross-sectional average blood flow velocity difference $\langle\Delta v\rangle$ between $\mathrm{A}$ and $\mathrm{B}$ cross-sections and a heartbeat pulse period averaged $\langle\Delta v\rangle$, denoted as $\langle\Delta \tilde{v}\rangle$, dependence on $t^{\prime}, I C P$ and $P e$ is shown in Fig. 7. It can be seen that when $P e-I C P \rightarrow 0$, then $\langle\Delta v>$ does not tend towards $<\Delta \tilde{v}>$, contrary to $\Delta S$. With the increase in and in ICP, $\langle\Delta v\rangle$ oscillation about $\langle\Delta \tilde{v}\rangle$ increases, this is due to nonlinear change in $\Delta S$.

$\Delta \hat{S}$ and $\langle\Delta \tilde{v}\rangle$ dependence on ICP and $P e$ is shown in Fig. $8 \mathrm{a}$ and b, respectively. When $\Delta \hat{\mathrm{S}}=0$, then based on the balance principle it should be that $I C P=P e$; however, from Fig. 8 a it can be seen that when $\Delta \hat{\mathrm{S}}=0$, then $I C P=P e \pm \varepsilon$, where $\varepsilon$ is the systematic error. From Fig. $8 \mathrm{~b}$ we can see that the same is true for the blood velocity, only the systematic error values based on $\langle\Delta \tilde{v}\rangle$ differ from the systematic error obtained based on $\Delta \hat{S}$; therefore, the systematic error based on $\Delta \hat{S}$ is denoted as $\varepsilon_{S}$ and the systematic error based on $\langle\Delta \tilde{v}\rangle$ is denoted as $\varepsilon_{v} \cdot \varepsilon_{S}$ and $\varepsilon_{v}$ are determined by evaluating the intersection point of curves, denoted as $(I C P=0$, $I C P=10, I C P=20, I C P=30)$ with the $\Delta \hat{S}=0$ axis. In this way obtained $\varepsilon_{S}=\{-1.48,-1.37$, $-1.17\} \mathrm{mmHg}, \varepsilon_{v}=\{-1.84,-1.76,-1.625\} \mathrm{mmHg}$, when ICP $=\{10,20,30\} \mathrm{mmHg}$. The difference between $\varepsilon_{S}$ and $\varepsilon_{v}$ is due to artery compliance in the region between $\mathrm{A}$ and $\mathrm{B}$ cross-sections. As the artery expands, due to the increase in arterial pressure, it creates additional volume between $\mathrm{A}$ and $\mathrm{B}$ cross-sections, which is occupied by incoming blood flow, and as the artery contracts this volume is reduced. However, when integrated over one heartbeat pulse period it turns out that the blood flow rate difference between $A$ and $\mathrm{B}$ cross-sections is non-zero, leading to the aforementioned difference in systematic errors. We denote systematic error due to compliance as $\varepsilon_{c}=\{-0.36,-0.39,-0.455\} \mathrm{mmHg}$. The systematic error due to compliance is dependent on the constitutive artery wall model, on the external material effect and on the initial lumen volume between A and B cross-sections. Initial lumen volume can be decomposed into the difference in length between A and B cross-sections and initial cross-sectional areas at $\mathrm{A}$ and $\mathrm{B}$ cross-sections.

The symmetry between A and B cross-sections can only be attained if the conditions are the same between them and therefore the systematic error would be 0 [10]. Based on our assumptions and boundary conditions we can differentiate what causes the systematic errors. In this case the symmetry between A and B is violated by arterial pressure difference, by difference in boundary conditions on $\Gamma_{3}$ and $\Gamma_{4}$ leading to differences in internal artery wall stresses and deformations and artery compliance.

Therefore, the systematic errors are due to $\langle\Delta \dot{p}\rangle$, difference in boundary conditions, which we will denote as $p_{a d d}$, and artery compliance. The difference caused by the boundary condition 


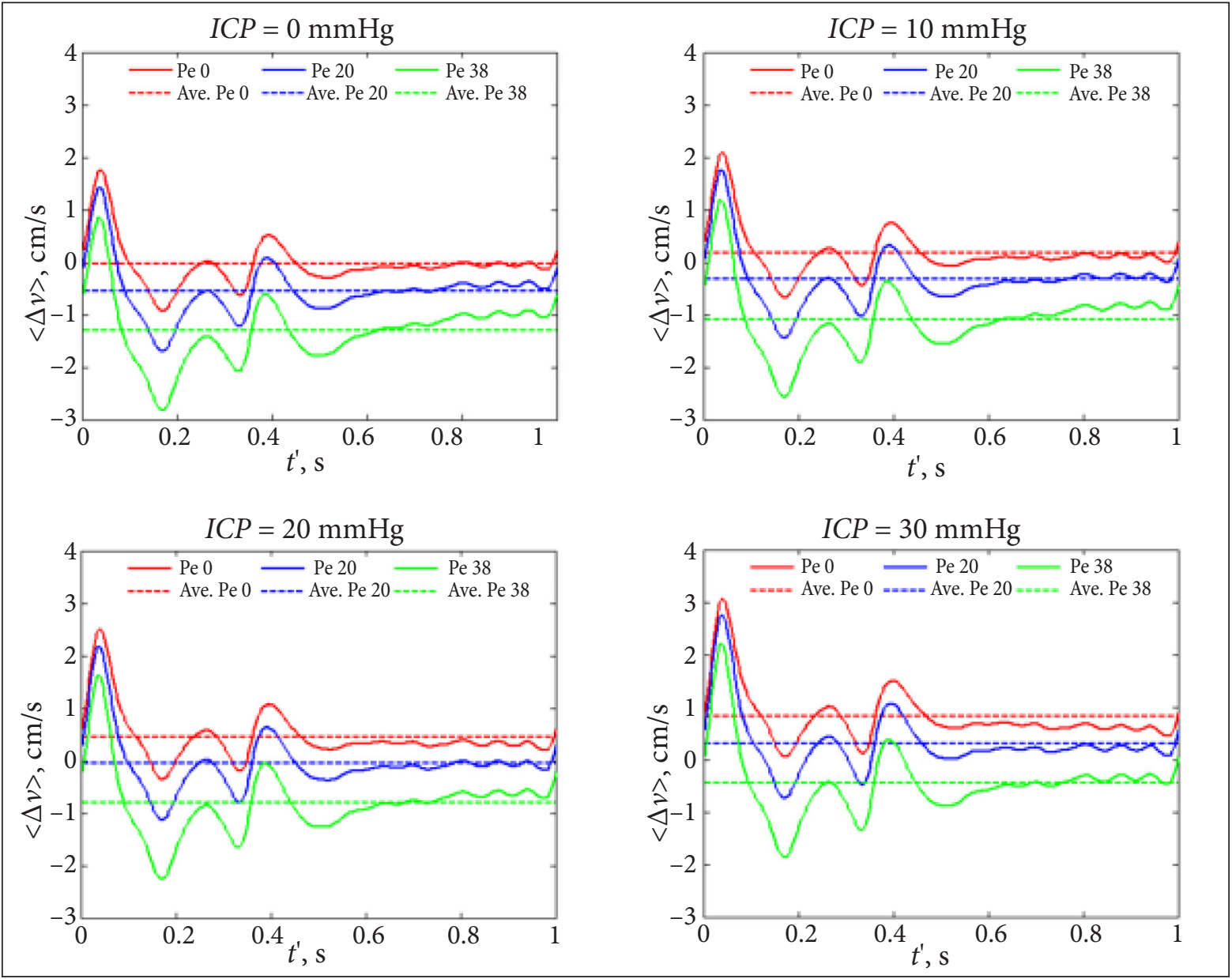

Fig. 7. Surface averaged blood flow velocity difference between $A$ and $B$ cross-sections, denoted as $\langle\Delta v\rangle$, and a heartbeat pulse averaged $<\Delta v>$, denoted as $\left\langle\Delta \tilde{v}>\right.$, dependence on $t^{\prime}, I C P$ and $P e$
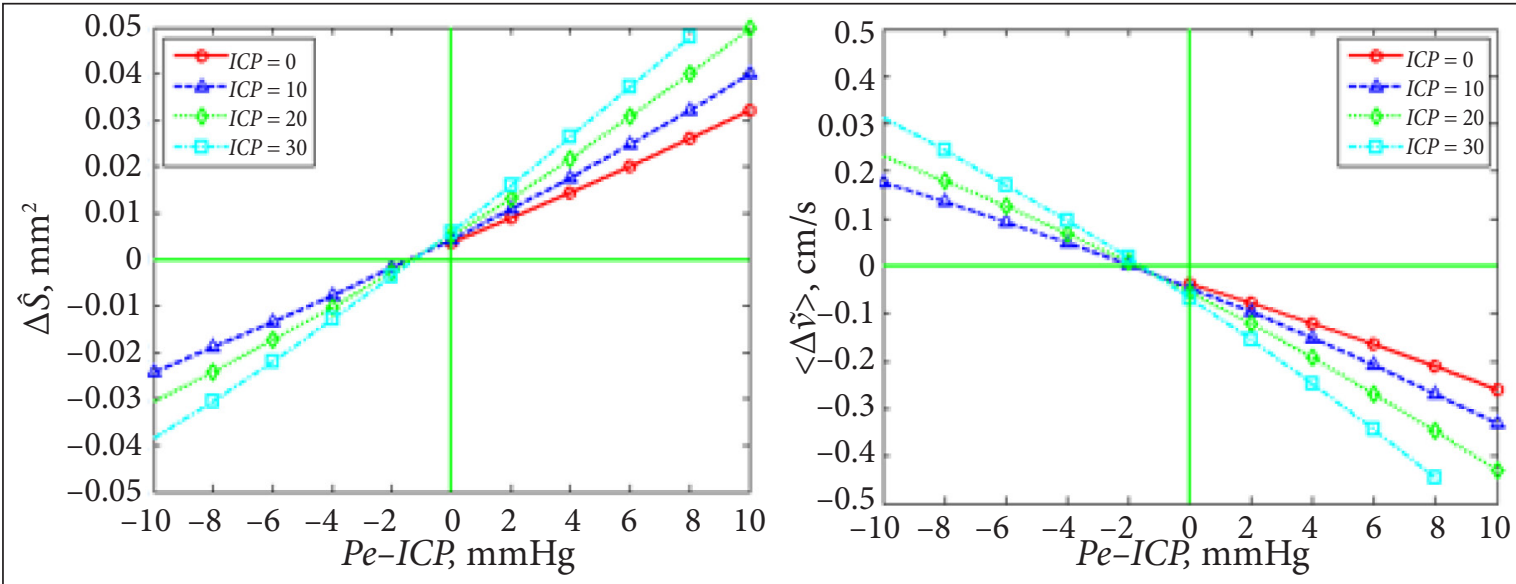

Fig. 8. A heartbeat pulse averaged cross-sectional area difference between $A$ and $B$ cross-sections $\Delta \hat{S}$ dependence on $I C P$ and $P e(a)$ and heartbeat pulse and surface averaged blood flow velocity difference between $A$ and $B$ cross-sections $<\Delta \tilde{v}>$ dependence on $/ C P$ and $P e(b)$

differences are different based on $\Delta \hat{S}$, we denote it as $p_{a d d, S}$, and on $\langle\Delta \tilde{v}\rangle$, we denote it as $p_{a d d, v}$. From Fig. $8 \mathrm{a}$, when $I C P=P e=\{10,20,30\} \mathrm{mmHg}$, then $p_{\text {add }, S}=\{-0.356,-0.229,-0.006\} \mathrm{mmHg}$, and from Fig. $8 \mathrm{~b} p_{\text {add }, v}=\{-0.716,-0.619,-0.461\} \mathrm{mmHg}$. Here $p_{a d d, v}-p_{a d d, S}=\varepsilon_{c}$. 
In [11], only one value of ICP was considered of $10 \mathrm{mmHg}$ and the bifurcation site of OA from internal carotid artery effect was incorporated and modeled, while in this study imaginary bifurcation site at boundary $\Gamma_{3}$ was prescribed to be immovable. In [11] it was obtained that $\varepsilon_{S}=-0.5 \mathrm{mmHg}, p_{\text {add }, S}=$ $0.26 \mathrm{mmHg}, \varepsilon_{v}=1.1 \mathrm{mmHg}, p_{\text {add }, v}=1.86 \mathrm{mmHg}$ and $\varepsilon_{c}=1.6 \mathrm{mmHg}$. While in this study, with ICP $=10 \mathrm{mmHg}$ these values were $\varepsilon_{S}=$ $-1.48 \mathrm{mmHg}, p_{\text {add }, S}=-0.356 \mathrm{mmHg}, \varepsilon_{v}=$ $1.84 \mathrm{mmHg}, p_{\text {add, },}=-0.716 \mathrm{mmHg}$ and $\varepsilon_{\mathrm{c}}=-0.36 \mathrm{mmHg}$. The values of $p_{\text {add, },}$ are mostly affected by the boundary conditions and therefore the difference in this value and in the value of [11] suggests that bifurcation site reduces the systematic error by $34 \%$, while immovable boundary increases it by $\{31.67 \%, 20.07 \%, 0.5 \%\}$ (with reference to $\langle\Delta \dot{p}\rangle$ and $I C P=\{10,20,30\} \mathrm{mmHg}$ ). However, the effect on systematic error in the model [11] may change with the change in $I C P$ as suggested by current investigation where $P_{a d d, S}$ decreased with ICP value reducing effect on systematic error. Artery compliance between selected A and B cross-sections increased the systematic error by $210 \%$ in the study of [11], while in this study it increased the systematic error by $\{32 \%, 34 \%, 39 \%\}$ (with reference to $\langle\Delta \dot{p}>$ and $I C P=\{10,20,30\} \mathrm{mmHg}$ ). The effect of compliance cannot be directly compared with the results of [11] as the initial volume between $A$ and $\mathrm{B}$ cross-sections, constitutive artery wall model and external material effect was different.

All effects influencing the systematic error, except the arterial pressure difference, can affect the systematic error in both ways (reduce it or increase it) and this may explain the low systematic errors obtained in experimental studies by other authors.

\section{Future model improvements}

Obtained results are limited to the particular worst-case scenario in terms of boundary conditions, which were prescribed to be immovable, while lengths of OA segments were physiologically relevant statistical means; however, the model could be further improved to incorporate the cases of difference in initial geometrical configuration, for example including patient-specific curvature. In reality, OA is curved, which can have an impact on the blood flow and on the artery mechanics. The incorporation of curvature is a non-trivial task comprising several steps, which can be defined in a very simple way as follows: the medical imaging data must be obtained through e.g. CT scan, MRI, etc., which must be further segmented resulting in a geometry that can be used for numerical simulations. Definition of the fiber orientations in a curved artery is another challenge.

\section{CONCLUSIONS}

The developed numerical model was used to solve the fluid-structure interaction problem of the blood flow in a straight, anisotropic, hyperelastic OA and the obtained results allowed us to perform an investigation of the systematic errors based on several characterizing parameters: blood flow velocity and cross-sectional area.

Based on the cross-sectional area difference between IOA and EOA segments $\triangle S$, when $P e-I C P$ tended towards zero, $\Delta S$ tended towards its heartbeat pulse averaged value of $\Delta \hat{S}$. No such effect was found for the difference of blood flow velocity $\langle\Delta v\rangle$ between selected cross-sections in IOA and EOA segments.

The systematic error was composed of pressure difference between selected cross-sections in IOA and EOA segments $\langle\Delta \dot{p}\rangle=\{1.112$, $1.124,1.141,1.164\} \mathrm{mmHg}$ with $I C P=\{0,10,20$, $30\} \mathrm{mmHg}$, respectively, and additional pressure term $p_{\text {add }, i}$, where $i$ corresponded to characteristic parameter (e.g. $\Delta S,\langle\Delta v\rangle$ ).

The systematic error based on $\Delta \hat{\mathrm{S}}$ was $\varepsilon_{S}=\{-1.48,-1.37,-1.17\} \mathrm{mmHg}$ with $I C P=\{10$, $20,30\} \mathrm{mmHg}$, respectively. The systematic error based on $\left\langle\Delta \tilde{v}>\right.$ was $\varepsilon_{v}=\{-1.84,-1.76$, $-1.625\} \mathrm{mmHg}$ with $I C P=\{10,20,30\} \mathrm{mmHg}$, respectively. The systematic error based on compliance between selected cross-sections in IOA and EOA segments was $\varepsilon_{c}=\{-0.36,-0.39$, $-0.455\}$ - with $I C P=\{10,20,30\} \mathrm{mmHg}$, respectively.

Asymmetrical boundary conditions between IOA and EOA segments resulted in the increase of systematic error by approximately $\{31.67 \%, 20.07 \%, 0.5 \%\}$ (with reference to $\langle\Delta \dot{p}\rangle$ and $I C P=\{10,20,30\} \mathrm{mmHg}$ ). The systematic error based on compliance between selected 
cross-sections in IOA and EOA segments resulted in the systematic error increase by approximately $\{32 \%, 34 \%, 39 \%\}$ (with reference to $\langle\Delta \dot{p}>$ and ICP $=\{10,20,30\} \mathrm{mmHg}$ ), while in the numerical model of [11] with $I C P=10 \mathrm{mmHg}$ the bifurcation site reduced the systematic error by $34 \%$ and the compliance increased the systematic error by $210 \%$.

We can conclude that the numerical model presented here examined the worst-case scenario in terms of boundary conditions, while lengths of OA segments were physiologically relevant statistical means; however, the obtained systematic errors still meet clinical standards of ANSI/AAMI where it is stated that the error should not exceed $\pm 2 \mathrm{mmHg}$ in the range of $0-20 \mathrm{mmHg}$ of ICP. Boundary conditions and compliance affects the systematic error in both ways (reduce or increase it); this may explain the low systematic errors obtained in experimental studies by other authors.

\section{ACKNOWLEDGEMENTS}

Grant of the Association Santakos Slènis (Santaka Valley, Lithuania) for the project "Investigation and numerical modeling of cerebral blood flow autoregulation and intracranial pressure in glaucoma patients" (GLAUMOD), 2018.

Received 5 June 2018 Accepted 25 September 2018

\section{References}

1. Roozenbeek B., Maas A. I. R., Menon D. K. Changing patterns in the epidemiology of traumatic brain injury. Nature Reviews Neurology. 2013. Vol. 9. No. 4. P. 231-236.

2. Mokri B. The Monro-Kellie hypothesis: Applications in CSF volume depletion. Neurology. 2001. Vol. 56. No. 12. P. 1746-1748.

3. Padayachy L. C. Non-invasive intracranial pressure assessment. Child's Nervous System. 2016. Vol. 32. No. 9. P. 1587-1597.

4. Hickman K. M., Mayer B. L., Muwaswes M. Intracranial pressure monitoring: review of risk factors associated with infection. Heart \& Lung: The Journal of Critical Care. 1990. Vol. 19. No. 1. P. 84-90.
5. Ragauskas A. et al. Method and apparatus for determining the absolute value of intracranial pressure. US8394025B22013.

6. Ragauskas A., Daubaris G., Dziugys A. Method and apparatus for determining the pressure inside the brain. US59514771999.

7. Ho H., McGhee C., Hunter P. Numerical analysis for the blood flow in a patient-specific ophthalmic artery. Medical Engineering \& Physics. 2012. Vol. 34. No. 1. P. 123-127.

8. Ragauskas A., Matijosaitis V., Piper I., Daubaris G. Clinical assessment of noninvasive intracranial pressure absolute value measurement method. American Academy of Neurology. 2012. Vol. 78. No. 232545. P. 1684-1691.

9. Ragauskas A., Daubaris G., Dziugys A., Azelis V., Gedrimas V. Innovative non-invasive method for absolute intracranial pressure measurement without calibration. Acta Neurochirurgica. Supplement. 2005. Vol. 95. No. 95. P. 357-361.

10. Misiulis E., Džiugys A. Effect of geometrical shape and boundary conditions on the stress distribution and deformations in ophthalmic artery numerical model. 13th Annual International Conference of Young Scientists on Energy Issues (CYSENI 2016), 2016. P. 363-370.

11. Misiulis E., Džiugys A., Navakas R., Striūgas N. A fluid-structure interaction model of the internal carotid and ophthalmic arteries for the noninvasive intracranial pressure measurement method. Computers in Biology and Medicine. 2017. Vol. 84. P. 79-88.

12. Sommer G., Holzapfel G. A. 3D constitutive modeling of the biaxial mechanical response of intact and layer-dissected human carotid arteries. Journal of the Mechanical Behavior of Biomedical Materials. 2012. Vol. 5. No. 1. P. 116-128.

13. Holzapfel G. Nonlinear Solid Mechanics: A Continuum Approach for Engineering. John Wiley \& Sons Ltd. 2000. 455 p.

14. Song M., Ma J., Huang Y. Fluid-structure interaction analysis of ship-ship collisions. Marine Structures. 2017. Vol. 55. P. 121-136.

15. Annerel S., Claessens T., Degroote J., Segers P., Vierendeels J. Validation of a numerical FSI simulation of an aortic BMHV by in vitro PIV experiments. Medical Engineering \& Physics. 2014. Vol. 36. No. 8. P. 1014-1023. 
16. Ogden R. W. Non-linear Elastic Deformations. $1997.532 \mathrm{p}$.

17. Stein E. Encyclopedia of Computational Mechanics. Chichester. UK: John Wiley \& Sons Ltd. 2004. 2336 p.

18. de Villiers A. M., McBride A. T., Reddy B. D., Franz T., Spottiswoode B. S. A validated patient-specific FSI model for vascular access in haemodialysis. Biomechanics and Modeling in Mechanobiology. 2017. P. 1-19.

19. Tu J., Inthavong K., Wong K. K. L. Computational Hemodynamics - Theory, Modelling and Applications. Vol. 58. No. 12. Dordrecht: Springer the Netherlands. 2015. 351 p.

20. Macrae R. A., Miller K., Doyle B. J. Methods in mechanical testing of arterial tissue: a review. Strain. 2016. Vol. 52. No. 5. P. 380-399.

21. Holzapfel G. A., Gasser T. C., Ogden R. W. A new constitutive framework for arterial wall mechanics and a comparative study of material models. Journal of Elasticity. 2000. Vol. 61. No. 1/3. P. 1-48.

22. Carew T. E., Vaishnav R. N., Patel D. J. Compressibility of the arterial wall. Circulation Research. 1968. Vol. 23. No. 1. P. 61-68.

23. Yosibash Z., Manor I., Gilad I., Willentz U. Experimental evidence of the compressibility of arteries. Journal of the Mechanical Behavior of Biomedical Materials. 2014. Vol. 39. P. 339-354.

24. Yossef O. E., Farajian M., Gilad I., Willenz U., Gutman N., Yosibash Z. Further experimental evidence of the compressibility of arteries. Journal of the Mechanical Behavior of Biomedical Materials. 2017. Vol. 65. P. 177-189.

25. Zdunek A., Rachowicz W. A mixed higher order FEM for fully coupled compressible transversely isotropic finite hyperelasticity. Computers and Mathematics with Applications. 2017. Vol. 74. No. 7. P. 1727-1750.

26. Babuska I., Suri M. On locking and robustness in the finite element method. SIAM Journal on Numerical Analysis. 1992. Vol. 29. P. 1261-1293.

27. Benselama A. M., Monnier J. Navier-Stokes ALE free surface flow with generalized Navier slip con- ditions. Droplet impact and attempt using Comsol Multiphysics 3.2.2007. 32 p.

28. Milnor W. R. Cardiovascular Physiology. Ed. 1. New York. NY: Oxford University Press. 1990. 509 p.

29. Trudnowski R. J., Rico R. C. Specific gravity of blood and plasma at 4 and $37^{\circ} \mathrm{C}$. Clinical Chemistry. 1974. Vol. 20. No. 5. P. 615-616.

30. Kuhl E., Maas R., Himpel G., Menzel A. Computational modeling of arterial wall growth: Attempts towards patient-specific simulations based on computer tomography. Biomechanics and Modeling in Mechanobiology. 2007. Vol. 6. No. 5. P. 321-331.

31. Hayreh S. S. Orbital vascular anatomy. Eye. 2006. Vol. 20. No. 10. P. 1130-1144.

32. Hart C. K., Theodosopoulos P. V., Zimmer L. A. Anatomy of the optic canal: A computed tomography study of endoscopic nerve decompression. Annals of Otology, Rhinology and Laryngology. 2009. Vol. 118. No. 12. P. 839-844.

33. Polak J. F. et al. Associations of carotid artery intima-media thickness (IMT) with risk factors and prevalent cardiovascular disease: comparison of mean common carotid artery IMT with maximum internal carotid artery IMT. Journal of Ultrasound in Medicine. 2010. Vol. 29. No. 12. P. 1759-1768.

34. Holdsworth D. W., Norley C. J. D., Frayne R., Steinman D. A., Rutt B. K. Characterization of common carotid artery blood-flow waveforms in normal human subjects. Physiological Measurement. 1999. Vol. 20. No. 3. P. 219-240.

35. Wizner B., Gryglewska B., Gasowski J., Kocemba J., Grodzicki T. Normal blood pressure values as perceived by normotensive and hypertensive subjects. Journal of Human Hypertension. 2003. Vol. 17. No. 2. P. 87-91.

36. Steiner L. A., Andrews P. J. D. Monitoring the injured brain: ICP and CBF. British Journal of Anaesthesia. 2006. Vol. 97. No. 1. P. 26-38.

37. Dunn L. T. Raised intracranial pressure. Journal of Neurosurgical Psychiatry. 2002. Vol. 73. P. 23-27. 
Edgaras Misiulis, Gediminas Skarbalius, Algis Džiugys

\section{NEINVAZIŠKAI NUSTATANT GALVOSPŪDI ATSIRANDANČIŲ SISTEMINIŲ PAKLAIDŲ IVERTINIMAS TAIKANT SKAITINI METODĄ}

\section{Santrauka}

Šiuo metu galvos smegenų traumos yra viena iš pirmaujančių neigalumo ir mirties priežasčių pasaulyje. Vienintelè prevencinè priemonė nuo pirminès galvos smegenų traumos yra didesnis atsargumas, o ištikus šiai traumai kliniškai galima taikyti įvarius metodus, mažinančius komplikacinių antrinių galvos smegenų traumų riziką. Vienas iš tokių metodų yra galvospūdžio stebėsena, leidžianti kiekybiškai ịvertinti situaciją ir priimti kokybiškesnius klinikinius sprendimus. Šiuo metu yra tobulinamas neinvazinis galvospūdžio matavimo metodas, kuris remiasi unikalia akies arterijos savybe. Akies arterijos dalis, atsišakojusi nuo vidinès miego arterijos, yra kaukolès viduje, ir ji veikiama galvospūdžio, kita dalis yra optiniame kanale, trečioji dalis - akiduobejje, kuri gali būti paveikiama papildomu išoriniu slègiu. Vertinant kraujotakos dèsningumus akies arterijoje galima nustatyti galvospūdžio vertę, tačiau atsiranda sisteminès paklaidos, kurias įvertinti eksperimentiškai yra sunku, o kartais netgi visai neįmanoma, tačiau panašius tyrimus galima atlikti pasitelkus skaitinius metodus.

Šiame straipsnyje pristatomas sisteminių galvospūdžio nustatymo paklaidų, atsirandančių taikant neinvazinị galvospūdžio matavimo metodą, tyrimas. Sudarytas skaitinis modelis leidžia tirti pulsuojančio kraujo tekejimą tamprioje akies arterijoje veikiant kaukolèje esančią jos dalị nuolatiniu galvospūdžiu, o akiduobèje esančią dali - išoriniu pridètiniu slègiu. Modelyje kraujo savybès tokios kaip Niutoninio skysčio, o kraštinėse kraujo tekejjimo sąlygose užduodamas periodiškai besikartojantis pasipriešinimas kraujo tèkmei. Šios kraštinès sąlygos generuoja kraujo tèkmès dinamiką atitinkančius eksperimentinius duomenis. Akies arterijos sienelès savybès aprašomos hiperelastiniu pluoštų struktūros modeliu, kuris remiasi histologine arterijos struktūra - kolagenų pluoštais, o prie fiziologinių slègių atkuria arterijos sienelès mechaninị sustangrèjimą.

Gauti skaitinių tyrimų rezultatai buvo analizuojami optimaliose matavimo plokštumose, t. y. kaukolèje esančios akies arterijos ir dalių viduryje akiduobeje pagal ilgi su normale, nukreipta kraujo tekejjimo kryptimi. Gauta, kad skerspjūvio ploto skirtumo dinamika tampa labai artima jos periodo vidurkiui, kai galvospūdis labai artimas pridètam išoriniam slègiui. Kraujo greičio dinamika šiuo efektu nepasižymejjo. Esant asimetriškai užduotoms įtvirtinančios kraštinès sąlygoms gaunamos sisteminès paklaidos tenkina klinikinius ANSI/AAMI reikalavimus, kad paklaida neviršytų $\pm 2 \mathrm{mmHg}$ galvospūdžio intervale nuo 0 iki $20 \mathrm{mmHg}$. Kraštinių sąlygų ir medžiagos tamprumo poveikis gaunamoms sisteminèms paklaidoms yra įvairus, gali padidinti arba sumažinti sisteminę paklaidą, kas galètų paaiškinti, kodèl eksperimentų metu gaunama sąlyginai maža sisteminè paklaida.

Raktažodžiai: galvospūdis, neinvazinis metodas, balanso būsena, akies arterija, fluido struktūros sąveika 